D.S. M'KIE, Essays in the Interpretation of Roman Poetry, Cambridge: Cambridge Classical Press, 2009, pp. xii + 307, ISBN 978-085455-042-5.

This book consists of three essays on the poems of Catullus and on Ovid, Heroides 1. Despite its title, two of the three essays and over three quarters of its pages are devoted to questions not of interpretation but of textual criticism. In the brief preface (p. vii) McKie suggests that the two are inseparable: "is not textual criticism, ultimately, the interpretation of an author?" Accordingly, his emendations tend to follow, and even to grow out of, a detailed interpretation of the text. This approach is not in itself unusual, but it is rarely applied as vigorously as here.

\title{
1. Notes on the TeXt of Catullus
}

The long first chapter (pages 1-190) is devoted to problems of textual criticism in Catullus. McKie proposes 38 conjectures of his own and reproposes 56 earlier ones, some of them long forgotten; and in 14 cases he argues for a reading that is found in one or more of the principal MSS'. The author's erudition, thoroughness and sensitivity make this chapter one of the most important recent publications on the textual criticism of Catullus. I will discuss a broad selection from his proposals.

One highlight of the chapter is M'Kie's masterly discussion of 17.3. After a highly erudite study of the Latin terms for a number of building materials he draws the convincing conclusion that Catullus must have written crura ponticuli assulis stantis in rediuiuis and meant 'the legs of the little bridge, standing on slithers of reused material'. assulis was already conjectured in 1566 by Statius, who took it in a very different sense. - No less interesting is McKie's solution for the notorious crux at 29.7f. perambulabit omnium cubilia / ut albulus columbus aut †ydoneus?, where he conjectures aut ciconius 'like a (male) stork'. Like many earlier scholars, he assumes that the pair of images in $\mathbf{2 9 . 8}$ must have illustrated Mamurra's promiscuity. However, his conjecture yields the image of two white birds with a strutting gait, which would aptly characterise Mamurra as he parades through the bedrooms of all and sundry. Are we to think of him wearing a white toga? However, it is a problem that the form ciconius is not attested elsewhere: storks are always called ciconiae, even in a context of procreation at Varro

\footnotetext{
${ }^{1}$ See the index on pages 301-3. In the following I will not give page references to individual problems discussed by $\mathrm{M}^{c} \mathrm{Kie}$, where these can be found in his index, nor will I give bibliographical references to secondary literature that can already be found on his pages.
} 
R.R. 3.5.6. There is another example in Catullus of an innovative gendered form of a noun denoting an animal, namely the Graecism leaena at 60.1 and 64.154 (cfr. Kroll on 60.1); but leaena is also attested elsewhere, while ciconius is not. - Many scholars have tried to emend 71.4. McKie analyses the poem and makes a case for conserving the transmitted reading a te, which already found favour with a few scholars in the past ${ }^{2} ; \mathrm{M}^{\mathrm{c} K}$ ie proves it correct. - At 44.15 he defends the transmitted reading me recuraui otioque et urtica against Ermolao Barbaro's conjecture ocimoque. His arguments are stylistic, but ocimoque would also yield the wrong meaning: the following lines show that Catullus attributes his recovery from a cold at least in part to Sirmio; here he cannot have attributed it to herbal medicine alone. - At 44.17 meum quod non es ulta peccatum $\mathrm{M}^{c}$ Kie argues convincingly, pace Fordyce and Thomson, that here Catullus should be addressing not his uilla at Sirmio, which is feminine (ulta), but Sirmio itself, which is masculine. Two remedies are available. Muretus' ultu' peccatum has recently been advocated by Trappes-Lomax, but $\mathrm{M}^{\mathrm{c}} \mathrm{K}$ ie does not want to introduce into the text any examples of ecthlipsis of the final $s^{3}$ and reproposes Baehrens' ultus erratum, which surely deserves serious consideration. It involves a major intervention into the text, despite McKie's insistence that erratum is "as similar to peccatum in shape as it is easily altered by the pious mind"; but such invasive emendation is certainly acceptable in Catullus. - McKie's case for the transmitted reading mulier at $\mathbf{6 3 . 6 3}$ is based in part on a valuable study of patterns of metrical resolution in poem 63 , and that for the humanistic conjecture tecta at $\mathbf{6 4 . 7 5}$ on a sensitive analysis of verbal repetition within poem 64. - Other readings for which he makes a convincing case are Statius'

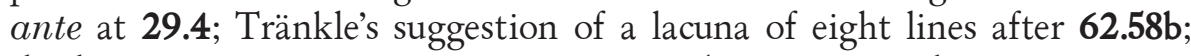
the humanistic conjectures Scyros at 64.35 , Eurotae and progignunt at 64.89, and taurum at 64.110; Bentley's quem at 63.43; Peiper's properans at 64.167; Housman's sacris at 64.287; Baehrens' residens at 64.387; and a series of readings that stand in some or all of the principal manuscripts OGR: 64.175 hic GR (here I used to prefer $O$ 's hec, but $\mathrm{M}^{c} \mathrm{Kie}$ adduces a convincing parallel at Verg. Aen. 4.10, and in fact $O$ routinely confuses the abbreviations for these two words), 64.276 uestibuli, 64.282 parit, $\mathbf{6 4 . 2 8 3}$ in distinctis (thus $G$, while $O$ and $R$ write indistinctis, but their scribes often attach a preposition to the following word), $\mathbf{6 4 . 3 7 3} \operatorname{coniunx}$, and $\mathbf{1 0 1 . 2}$ aduenio ... frater. His arguments for many of these readings constitute a major contribution to Catullan textual criticism.

\footnotetext{
${ }^{2}$ See the commentaries of Achilles Statius (1566) and Alexander Riese (1884) ad loc., as well as G. Lafaye, $R P h$ n.s. $46,1922,71-3$.

${ }^{3}$ Catullus' principal MSS. present us with only one example of ecthlipsis of final $s$ at 116.8 dabi(s) supplicium. J.M. Trappes-Lomax makes a case for reconstructing more examples of this phenomenon in Catullus: A Textual Reappraisal, Swansea 2007, 6-8.
} 
Two of McKie's suggestions are only partly convincing. He makes a strong case for Jocelyn's deletion of $\mathbf{2 9 . 5}$, but it is hard to see how this could have displaced a genuine verse of Catullus', as he suggests. - At 29.23f. urbis opulentissime / socer generque he argues for Haupt's orbis o potissimi. While o potissimi is very attractive, we should surely retain urbis, which is just right: the sphere of influence of Caesar and Pompey does not extend to Araby or Cathay, but only to Rome and her dominions. Catullus never pays the targets of his invective the compliment of giving them a cosmic dimension.

In some cases it is hard to reach certainty. At 14.8f. hoc nouum ac repertum/munus $\mathrm{M}$ 'Kie conjectures peramplum 'very great'. As is well known, repertum is not attested elsewhere in the sense 'recherché, but a word with such a meaning would characterize admirably Calvus' novel gift to Catullus. On the other hand, peramplum would be impeccable Latin, but it would be rather colourless. One can choose repertum (as I would) or peramplum, and live with its disadvantages; but perhaps we should look for a different solution. -At 62.21f. qui natam possis complexu auellere matris, / complexu matris retinentem auellere natam Housman, Vannini and $\mathrm{M}^{\mathrm{c} K i e}$ all conjectured renuentem independently of each other. The conjecture is palaeographically felicitous, but it yields the surprising image of the young bride indicating her displeasure at being torn away from her mother merely by a nod. One would expect a more vigorous reaction. Diggle conjectured trepidantem, which would suit the context well, but it is less close to the transmitted text. In fact there are parallels for retineo being used in a context of embraces (note Cic. Planc. 100 ui me ... Plancius et complexu suo retinuit and ibid. 102 te ... retinebo et complectar), which strongly suggest that here too the verb must be genuine. But there are two problems with retinentem: the verb is used very rarely without an explicit object $^{4}$; and elsewhere it always describes the action of keeping back someone else who is being carried away rather than holding on to something as one is being carried away oneself. Here Baehrens' conjecture retinente would give the verb its usual meaning. I find it unattractive to let natam stand without another word qualifying it, but perhaps this is not too high a price to pay for putting the Latin in order. -At $\mathbf{6 3 . 5}$ deuoluit †iletas sibi pondera silice (here the principal MSS. write deuolsit and pondere silices; the former was corrected by Haupt, the latter by Avantius) McKie reproposes Arthur Palmer's conjecture ipse. But it is hard to see how this could have given rise

\footnotetext{
${ }^{4}$ retineo is used without an explicit object in hasty exclamations at Ter. Phor. 982 adsequere, retine, dum ego huc seruos euoco, where one has to supply illum, and at Pacuv. frg. trag. 263 Ribbeck $=199.8$ Schierl retinete, tenete! opprimit ulcus, where one probably has to supply me. At Lucr. 6.519 the meaning of the verb is different: see Bailey ad loc. The participle retinens is sometimes used adjectivally with a genitive rather than an accusative, but there seem to be no other attestations of it being used on its own (see the $O L D$ s.v.).
} 
to the transmitted reading iletas. -At 64.60f. quem procul ex alga maestis Minois ocellis ... prospicit McKie argues against Falcoburgius' conjecture

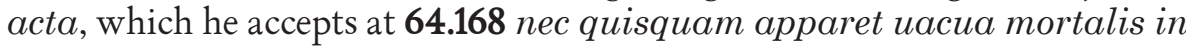
$a \lg a^{5}$. In his view alga makes sense in the former passage because it locates Ariadna at the point where seaweed accumulates, that is to say, "in the sea in water close to the shore and at the water's edge" (p. 77), while at line 64.168 alga should be emended to acta because of a parallel at Aeneid $5.613^{6}$. But there Virgil writes at procul in sola secretae Troades acta, which also echoes Catullus 64.60; and in both its Catullan occurrences alga would yield a meaning that seems to me too bathetic for such a refined epyllion: 'whom the daughter of Minos beheld from afar, out of the seaweed, with mournful eyes' (64.60f.) and 'nor does any man appear among the empty seaweed' (64.168). At $64.168 \mathrm{M}^{c} \mathrm{Kie}$ accepts Nicolaus Heinsius' palaeographical explanation of the corruption, but one should explain in any case how it can have yielded a proper Latin word. I suspect that a later age no longer understood the word acta, which had fallen into disuse soon after the late Republic, and turned it into something more familiar. - It is hard to reconstruct the end of line 116.7 contra nos tela ista tua euitabimus amitha $(O)$ or amicta $(G R)$. $\mathrm{M}^{\mathrm{c}} \mathrm{Kie}$ proposes aucta, which is ingenious but unconvincing. augeo means 'to increase', not 'to multiply'; I would want to see a parallel for it in the latter sense before putting it into the text.

Some of McKie's proposals can be ruled out. At 6.12 the principal manuscripts read inista $(O)$ or ni ista $(G R)$ preualet nihil tacere, which is unmetrical gibberish except for the last two words. McKie conjectures nimirum ista nihil ualet tacere, but nimirum 'of course' would be out of tone with the vigour with which Catullus is criticizing Flavius in this passage. cur? in the following line confirms that whatever once stood here, it was not obvious or uncontroversial. -At 10.9f. nihil neque ipsis / nec praetoribus esse nec cohorti $\mathrm{M}^{c} \mathrm{~K}$ ie would replace nec praetoribus with exactoribus 'for the tax collectors'; but these individuals make no further appearance in the poem, nor elsewhere in Catullus, and nec cohorti only makes sense after a reference to a provincial official. -The problems with 14.13-5 quem tu scilicet ad tuum Catullum / misti continuo ut die periret / Saturnalibus, optimo dierum are well known: it is hard to make sense of continuo ... die $e^{7}$. McKie conjectures diu and takes line 14 to mean 'you sent it immediately, so that he should die a lingering death'. But the

${ }^{5}$ Like all recent scholars, McKie attributes the conjecture acta at 64.60 and 64.168 to Nicolaus Heinsius, but the great Dutch scholar attributed it to Falcoburgius (Gerhard Falkenburg, 1535-1578): see pages 171 and 174 of this journal. I would like to thank José Antonio Bellido for having shown me his collation of Heinsius' marginalia on Catullus before it was published.

${ }^{6} \mathrm{M}$ cKie also compares a parallel at Prudentius, Symm. 1.136, but the Christian poet is surely imitating Virgil rather than Catullus, whom he may never have read.

${ }^{7}$ See S.J. Heyworth, PCPhS n.s. 44, 1998, 89, who proposed continuo ut periret <ipsis>. 
potent venom in Calvus' gift could be expected to have an immediate effect, and line 15 shows that it would have dispatched Catullus on the very day of the Saturnalia; so surely not slowly or gradually (diu). - At 21.10f. doleo, quod esurire / † me me puer et sitire discet McKie would write insane; but Catullus is criticizing Aurelius for having shamelessly seduced his boyfriend (puer), and not his boyfriend for having been so foolish as to follow. I thought of writing iam meus puer, or even iam puer meus, which would make meus less emphatic; but both are more bland than I would wish. - In line $25.5 \mathrm{M}$ Kie would write conuiua cum lucri uias ostendit oscitanter, which is excellent Latin, but its abstract elegance is far removed from the sleaziness and the incisive directness of Catullus' invective. - No less controversial is 29.20, where the principal MSS. read hunc Gallie timet et Britannie. M'Kie would write habetne cuncta Galliae et Britanniae? But 'Does he own everything that Gaul and Britain once possessed?' is a surprisingly pedantic question, the more so after 29.1-4, and it is not clear whether cuncta could be used with the genitive of the name of a region to indicate all its wealth (cuncta Galliae). The closest parallels for this are in the fourth-century A.D. Latin translation of Dictys of Crete, where cuncta regni is used first for 'the fortunes of the kingdom' (3.21) and then for 'the full powers of kingship' (6.9). There appear to be no earlier parallels, nor any closer ones $^{8}$. - At $\mathbf{5 2 . 2}$ sella in curuli struma †nouius sedet Catullus' first commentator Parthenius proposed to write Nonius, which was already read by Pliny the Elder ${ }^{9}$. M'Kie makes the astute observation that we already know of an infamous politician in contemporary Rome who had the rare condition known as struma (swollen glands in his neck), namely Vatinius, who is mentioned in the next line. He infers that this line too must refer to Vatinius, and conjectures nobilis. But that venerable word would be very much out of place in such a context of stinging invective; the dramatic effect of line 4 relies on the name of Vatinius being dropped unexpectedly, so he will not have been mentioned in line 3; Catullus surely supported his thesis that life was no longer worth living (lines 1 and 4 ) with more arguments than just Vatinius' rise to high office (lines 2 and 3, in McKie's reconstruction); and Pliny not only read Nonius in his manuscript of Catullus, but was also able to identify this individual, as well as his son and grandson. Perhaps both Nonius

\footnotetext{
${ }^{8}$ On cuncta with the genitive see further TLL 4.1402.44-59. I suspect that 29.20 may have been reconstructed correctly by Badian, who wrote nunc Gallicae timetur et Britannicae (i.e. praedae). This makes excellent sense and is close to the transmitted reading. It is a problem that in this poem consisting (mostly) of pure iambs nunc results in a spondaic first foot; but compare line 3 Mamurram, which has a long initial syllable (thus 57.2 Mamurrae - the Aeolic base is never iambic in Catullus - and esp. Hor. Ser. 1.5.37 in Mamurrarum). Perhaps nunc seemed indispensable to Catullus at the climax of his indignant outburst, its slight metrical irregularity notwithstanding.

${ }^{9}$ N.H. 37.81 filius strumae Noni eius, quem Catullus poeta in sella curuli uisum indigne tulit.
} 
and Vatinius had a struma after all - or could Struma have been a rare cognomen, as is sometimes believed? -At 66.1 omnia qui magni despexit lumina mundi modern editors print Calphurnius' conjecture dispexit. McKie reproposes Bentley's conjecture descripsit. But his arguments are not compelling the Callimachean original is somewhat obscure here, and the parallels he detects at Verg. Ecl. 3.41 and Aen. 6.850 would not be close), and comperit in the following line suggests that here too we need a verb of discovering and not one of describing. - McKie would emend both 66.9 and its Callimachean original. The transmitted text of 66.8-10 runs caesariem ... quam multis illa dearum / leuia protendens brachia pollicita est; McKie would write uotis illa deorum. At Callimachus, Aetia frg. 110.8 Pfeiffer the

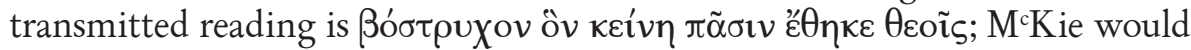
write $\pi i \sigma \tau \imath v$. But it is not easy to translate uotis deorum pollicita est, or to explain the grammatical role of uotis. Either the transmitted text is correct, or one only needs a minor emendation such as cunctis illa deorum (with Haupt) or simply multis illa deorum. That leaves one with no reason to emend Callimachus.

An interesting problem arises at $\mathbf{1 2 . 8 f}$., where the principal MSS. read est enim leporum / di(s)sertus puer ac facetiarum; many editors accept Passerat's conjecture differtus. McKie conjectures dispectus puero, but elsewhere dispectus always means 'the act of discerning' and never 'the ability to discern'. He bases his conjecture on a detailed analysis of Catullus' use of est in initial position (pages 10-13), which is uncharacteristically off the mark. He appears to assume that initial est must itself be emphatic, and equates this usage with the emphatic auxiliary verb in English; so he translates 35.17f. est enim uenuste / Magna Caecilio incohata mater as 'Caecilius' Magna Mater has been, you would agree, charmingly begun'. But there the point is not that Caecilius has actually started writing his poem, but that he has started it in such a way that a girl of considerable culture could read it and fall in love with him (lines 13-17). What swept her off her feet was not the poem's sheer existence, but its quality. So the emphatic word in lines $17 \mathrm{f}$. is not est but uenuste, and one should translate 'Caecilius' Magna Mater has been, you would agree, begun charmingly'. Initial est in Catullus evidently highlights an adverb, an adjective, or a comparable word in the predicate: compare 23.5 est pulcre tibi cum tuo parente 'you do get along well with your father' and 66.15 estne nouis nuptis odio Venus? 'do young brides hate Venus?' At $\mathbf{5 0 . 2 1}$ editors write est uemens dea ${ }^{10}$; McKie recognises that these words should mean 'she is a mighty goddess' and proposes to write uemens est dea; but there is no need for this, as they already mean what they should. To return to $12.8 \mathrm{f}$., there McKie's conjecture gives rise to a possessive use

${ }^{10}$ This was proposed by Statius in his commentary of 1566 ; the principal MSS. write est uehemens dea. 
of est, as in est mihi domus 'I have a house'. In fact Catullus does not use initial est in this way, but only (as we have just seen) in order to highlight an adverb, an adjective, or a comparable word in the predicate. In 12.8f. that has to be an adjective. Two candidates are at hand: the transmitted reading disertus, and Passerat's differtus. McKie rightly insists that disertus results in problems with the metre (an isolated opening iamb in the aeolic base) and with the meaning (it is not clear how to take the genitives leporum ... ac facetiarum). As for differtus, he notes that it "is not elsewhere known to take the genitive" and "[o]f the seven instances in TLL s.v. all five ... which govern other words take an ablative" (p.9, with n. 30). But that is not a broad sample, and its the use with the genitive could simply be rare; or it could be an innovation by Catullus on the analogy of plenus with the genitive.

Textual corruption does not give itself away by any external sign, and it is often hard to tell whether or not a passage is corrupt, especially if it displays an unusual characteristic. Textual critics of the more enterprising sort often end up altering passages that are probably not corrupt, and $\mathrm{M}^{\mathrm{c}} \mathrm{Kie}$ is no exception. 6.17 ad caelum lepido uocare uersu was already suspected by Nisbet, who conjectured leuare. McKie proposes sonare; but there are no parallels for sonare aliquem in aliquem locum. I suspect that uocare may be right after all: compare OLD s.v., 2. - At 29.19 (praeda) Hibera, quam scit amnis aurifer Tagus McKie argues that "the Tagus, through its gold (expressed in aurifer), is the booty" (p. 34) and where De Clercq van Jever had conjectured qua nitescit, he proposes qua tumescit. But the booty from a conquered territory included money, possessions, and prisoners, so Catullus need not have limited the Spanish booty to the gold in the sands of the Tagus; on the other hand it could well have been said about a river that it knew about something, which is said about a city and a mountain at $4.13 \mathrm{f}$., and about a star, some rocks and a promontory at Verg. Aen. 11.259f. (both passages are quoted by $\mathrm{M}$ K Kie). I am reasonably confident that the transmitted reading is genuine. - The subject of line $\mathbf{6 4 . 2 8 7}$ †minosin linquens doris celebranda choreis is the river Penios, and its object is the wooded gorge of Tempe. McKie conjectures celebrata, as he believes the river is 'leaving [the gorge], thronged by the women of Thessaly' (Haemonisin, suggested by Nicolaus Heinsius). But it is not clear when and why the women of Thessaly should have thronged this gorge, nor why this fact should be mentioned here. The transmitted reading celebranda works excellently, especially if it follows a reference to minor deities who are likely to reside in such a place: Penios could be leaving [the gorge] to be thronged by river nymphs' (Naiasin, conjectured by Haupt). The gerundive is often used with the dative of agency, as at Ov. Met. 15.844 constitit alma Venus

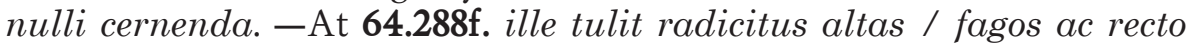
proceras stipite laurus McKie would write alnos / fractas. Here radicitus means not 'by the roots' $(O L D)$ but 'roots and all': the river-god is carrying 
the trees with the roots still attached; so fractas would be out of place. McKie makes the erudite objection to the transmitted text that beach trees (fagi) do not grow by rivers, but it is the question whether Catullus knew that and if yes, whether he had it in mind here. The poet seems to focus not on the very banks of the Penios, but on the mountainous woodland through which it flows; and that is where the beech trees stood, before they were torn out by a personified river-god (not by the natural force of a flooded river) to serve

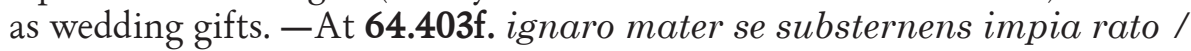
impia non uerita est diuos scelerare penates McKie would follow Nisbet in replacing the second impia with improba, but the awkwardly juxtaposed pair of adjectives in impia mater / improba runs no more smoothly than the transmitted text, and the repetition of such a highly charged term as impia could surely be justified on grounds of emphasis. - Poem 89 explains the good fortunes of Gellius, and in particular the sexual practices that keep him thin. At 89.3f. tamque bonus patruus tamque omnia plena puellis / cognatis McKie would write tam somnia; but erotic dreams do not keep one thin; and they would make for a very trifling reproach by the standards of Catullan invective. Catullus surely accused Gellius of actually committing incest, not of having frequent dreams about it. omnia is very likely correct.

For many of his proposals $\mathrm{McKie}$ reconstructs a plausible iter corruptionis and displays a grasp of palaeography that is very impressive indeed. His reconstructions involve minuscule scripts ranging from the pre-Carolingian and the early Carolingian (p. 81) to the Gothic (pages 32f., 48, 71, 99, 106, 114f., cfr. pages 3 and 179, and the illustrations on pages 189f. $)^{11}$. Future scholars will have to think about these reconstructions.

To sum up, I am often convinced by McKie where he defends the transmitted reading or advocates an earlier conjecture, but I would only accept one conjecture of his own. Other critics may well draw a slightly different balance - it can take a long time to determine the worth of a conjecture, as is shown by the fact that assulis at Cat. 17.3 was first proposed by Statius in 1566 , but it was given a new interpretation and proven correct by $\mathrm{M}^{\mathrm{c}} \mathrm{Kie}$ in 2009 - but I am reasonably certain about the overall conclusion that he is more successful at interpreting the text of the manuscripts and reproposing earlier conjectures than at making conjectures of his own.

Ironically, I suspect that this may follow from his method of arriving at a conjecture through the interpretation of, and inference from, the text. If an excellent scholar studies a passage in minute detail, that is likely to lead to valuable results, but there is no guarantee that the correct reconstruction of the passage will occur to him in the end. An old name for emendation

\footnotetext{
${ }^{11}$ There are strong indications that Catullus' pre-archetype was written in Gothic minuscule: see D.F.S. Thomson, Catullus Edited with a Textual and Interpretative Commentary, Toronto 1997, 24-5.
} 
is diuinatio, as if it required supernatural inspiration. Although different scholars work in different ways, there is some truth to the words of R.G.M. Nisbet that " $\mathrm{t}]$ he Muse of Textual Conjecture ... only visits those who have worked, but she does not visit us when we are actually working” ${ }^{12}$. This could have to do with the number of excellent scholars who have studied the masterpieces of Classical literature before us: those conjectures that can be made easily through inference may be the low-hanging fruit most of which has already been picked.

McKie tries to solve textual problems that have proven too much for Avantius, Statius, Scaliger, Heinsius and Lachmann, which is inevitably a risky enterprise. Sometimes he succeeds; indeed, in many cases he will surely turn out to have made a lasting contribution to Catullan textual criticism. Sometimes he does not; but even here he often casts valuable new light on the text, or he encourages one to try one's own hand at a difficult problem. To be sure, I do not subscribe to many of his proposals, but it hardly seems too much to ask of its prospective readers that they should read his book with critical eyes.

Catullus' poems have been transmitted to us in a dire shape. As long as Herculaneum or Egypt do not yield us a better text, we must rely on the patient work of scholars such as McKie if we want to be able to read, understand and appreciate them. This effort has gone on for over half a millennium now, and has reconstructed and illuminated much of Catullus' poetry. There remain problems to be solved, probably including some that have not yet been noticed; and our grasp of many passages remains slippery. It is of great importance that the effort of reconstructing what Catullus wrote (and how it should be understood) should continue due to scholars such as $\mathrm{M}^{\mathrm{c}} \mathrm{K}$ Kie. We need more books like this.

\section{Language and the Poetic Voice: Catullus 68A}

The second chapter of the book (pages 191-248) offers a close reading of one of the most difficult parts of the Catullan corpus, the letter in verse that is known as poem $68 \mathrm{a}(68.1-40)^{13}$. McKie first sets out the principles underlying his interpretation. "As a poem, the work we are given naturally leaves the realm of private correspondence which it at least purports to reproduce and acquires the capacity to reach the ears of readers who may have no personal

${ }_{12}$ R.G.M. Nisbet, "How Textual Conjectures Are Made", $M D$ 26, 1991, 6s-91, on p. $91=$ R.G.M. Nisbet, S.J. Harrison (ed.), Collected Papers on Latin Literature, Oxford 1995, 361.

${ }^{13}$ Here I must declare an interest, as I have written about this text recently: see D. Kiss, Catullus 68 Edited with an Introduction and a Detailed Commentary, Diss. Scuola Normale Superiore di Pisa, 2009 = henceforth Kiss, Catullus 68. A revised version should soon appear in print. It is still contested whether the first forty lines of Catullus 68 constitute a separate poem. $\mathrm{M}^{\mathrm{c} K i e}$ believes that they do (see esp. p. 193), and the arguments in favour of this appear compelling: see Kiss, Catullus 68, 10-33. 
acquaintance with either of the two writers" - that is to say, of the poet and of his friend who had written the letter he is replying to. Previous scholars have failed to understand the text because we "have lost ... the natural ear to pick up the semantic, syntactical and lexical signs by which Catullus guided his readers through what has become for us a maze of multiple turnings" ( $\mathrm{p}$. 192). McKie aims to find these signs and to interpret the poem with their aid.

Catullus 68a has been studied by generations of scholars, but McKie's sensitive analysis solves longstanding problems and casts light on hitherto unnoticed features. For example the demonstrative pronoun in line 2 conscriptum hoc lacrimis mittis epistolium has caused much perplexity, as it is normally used in Latin epistolography for the letter one is writing, and not for the letter one is replying to. McKie explains that here it is used for the sake of the general reader, as Catullus "indicates that he has the letter [he is replying to] open before him" (p. 195). With similar perceptivity he notes that fregisti in line 21 echoes naufragum in line 2 (p. 205). As for the widely held view that the books Catullus mentions in line 33 are "necessary accompaniments of the allusive Alexandrianising poet who is unable to compose without them", he makes the sensible objection that this raises "wide-reaching questions about Catullus' compositional techniques and their relation to much of his actual output" (p. 219, with n. 52).

His interpretation of the text can be outlined as follows. Catullus 68a is the reply to a letter from Manlius ${ }^{14}$ that "was joky, witty, and playful, presenting his upset in love as a condition of life-threatening proportions" ( $p$. 228). Manlius asked him for love poems of his own, which Catullus referred to as munera et Musarum ... et Veneris (line 10; see p. 200). In his reply the poet uses "the politest and most touching of terms" to refuse the request of his friend (p. 218). And given that his addressee is no other than the young L. Manlius Torquatus, who belonged to one of the most ancient families of Rome, his language "displays ... signs of the deference to be expected in addressing a correspondent of considerably superior social standing” (p. 246).

As we have seen, McKie's strategy is to track down the markers in the text that enable a sensitive general reader to understand it. Like generations of earlier interpreters, he assumes that the poem must make sense not only for its addressee, Manlius, but also for the general reader. It is the question whether this is really the case, and whether Catullus 68 a really offers the general every piece of information that one needs to understand it in full. Elsewhere I have argued that poem 68a was written for two kinds of public: for its addressee, Manlius, who could understand it in full; and for the general reader, who can follow it in broad lines, but is not given all the facts about Manlius' misfortune, his present condition, and the exact nature of the help

${ }^{14}$ McKie (p. 193, with n. 2) shows that "good traces of [the name Manlius] survive in the manuscript tradition". I fully agree: see Kiss, Catullus 68, 34-8. 
that he has asked from Catullus ${ }^{15}$. While McKie tries to extract from the text all the key elements of Manlius' story, I believe that some of these elements are simply not there, so we are not in the position to reconstruct the story with certainty.

To give one example, $\mathrm{M}^{\mathrm{c}} \mathrm{Kie}$ infers from the fact that Manlius is sexually deprived (lines 5f.) that his misfortune must have been an "upset in love" (p. 228). That is possible, but not certain: many kinds of traumatic events could lead to sexual deprivation, and any number of them could be followed by it. If we accept McKie's hypothesis that the poem must offer us all the clues necessary to understand it, then we must interpret it with the help of whatever pointers it may offer, however vague they may appear. Manlius is known to have suffered a major blow; the only concrete details that are given about his situation is that he is sexually deprived, and that he cannot distract himself at night by reading (lines 5-8); being deprived of distracting reading-matter is not likely to constitute a major blow; so if the text must already offer clues about Manlius' misfortune, then his misfortune must be of a romantic or sexual nature. But it is the question whether this characterizes it closely enough - most readers would probably want to know more about Manlius' misfortune than that it was a romantic misadventure of some sort; and earlier scholars have made a bewildering array of proposals as to what exactly may have happened. McKie's reconstruction is one more such proposal; its novelty lies in its clarity and in its sensitivity to all kinds of detail. I believe on the other hand that Catullus wrote a letter in verse to Manlius that a general reader could understand only in broad lines, without receiving any potentially sensitive information about the personal circumstances of the addressee. We are not told what happened to Manlius; and in my view it is best to accept that we will never get to know it.

McKie sees an element of irony in the exchange between Manlius and Catullus, but there are no clear signs of this in the text, and Catullus need not have replied ironically to a friend who presented a mere "upset in love as a condition of life-threatening proportions" (p. 228): poems such as 8, 76 and 85 show that Catullus could take romantic liaisons very seriously indeed. I also have doubts about the "signs of deference to be expected in addressing" a social superior that $\mathrm{M}^{\mathrm{c} K i e}$ detects in the text (p. 246): these merely appear to indicate tact, politeness, and a degree of surprise at the fact that someone who was not a close friend has taken Catullus into his confidence. Any degree of respect for authority would be surprising in a poet who addressed that illustrious and powerful aristocrat C. Iulius Caesar as 'you faggot Romulus ${ }^{16}$. This removes McKie's argument for identifying the addressee of the poem with the young aristocratic politician L. Manlius

${ }^{15}$ Kiss, Catullus 68, 44-8.

${ }^{16}$ Thus 29.5, if genuine, and 29.9 cinaede Romule. 
Torquatus. I believe that the identification may well be correct, but I do not see how this could ever be proven wrong or correct with the help of the text, and of all other information at our disposal today ${ }^{17}$.

\section{Ovid Needn't Nod: Corruption and the Place of Textual Criticism in HEROIDES 1}

The last chapter (pp. 249-94) is devoted to another verse letter, Ovid's Heroides 1. Ovid's poem purports to be a letter from Penelope to Ulysses. Its dramatic date is set to coincide with part of the Odyssey, after Ulysses arrives in Ithaca in disguise, and Telemachus returns back from Sparta and Mycene, but just before Ulysses reveals his identity and murders the suitors. Nevertheless, Ovid's poem contradicts the Odyssey on a number of points, which has perplexed earlier interpreters.

In order to resolve these contradictions and to remove a number of other blemishes from the text $\mathrm{M}^{\mathrm{c}} \mathrm{Kie}$ proposes seven conjectures, argues that lines 37-40 have been interpolated (as it appeared to Bentley) and that they have displaced four genuine lines, and reorders lines 99-116 so that they stand in the sequence 103-6, 109-14, 107f., 99f., 101f., 115f.

Is it right to intervene to such an extent into a text of only 116 lines that is not known to be particularly corrupt? I think that the answer is yes, though one may disagree about which passages should be emended, or how. For example, line 15 is transmitted as siue quis Antilochum narrabat ab Hectore uictum. Here it is a problem that Antilochus was known to have been killed not by Hector but, famously, by Memnon (McKie, pages 254f.); and it is a stylistic blemish that Hectore clashes with Hectoreo in the previous line - which may be the source of the corruption. So one has to emend; the question is only how. McKie would write cuspide uictum, which is better than Housman's ab hoste reuictum, or Politian's unacceptable Memnone uictum. Likewise, he gives convincing arguments for Bentley's hitherto unpublished deletion of lines 37-40 (pages 259-268); and if an interpolator meddled with one passage, he may have intervened elsewhere as well. I am also convinced by McKie's conjecture quid Amphimedonta at line 91, where he transmitted reading Medontaque dirum bluntly contradicts the Odyssey. I do have doubts about his re-arrangement of the last lines of this poem: it appears unlikely that lines should have been re-ordered to such an extent.

I am not an Ovidian scholar, and would rather leave to others the task of considering every proposal in detail. But it is clear that this is an important study of a very problematic text, and it will have to be read carefully by all those who will want to understand Heroides 1.

${ }^{17}$ Kiss, Catullus 68, 34-43. 


\section{Appendix: Two editions of Catullus}

On pages 297-300 McKie prints a useful list of the sixty Catullan editions and commentaries that he refers to in the book, which include most such titles of importance ever to have appeared. I will comment briefly on two of the editions that he mentions.

In his entry on the younger Janus Dousa's rare 1592 edition of Catullus, Tibullus, Propertius and some other texts, $\mathrm{M}^{\mathrm{c}} \mathrm{Kie}$ mentions that "[a]n earlier Leiden 1588 version of the edition ..., possibly no longer extant, is reported by the Bipontine (1783) editors in their Index Editionum, and the poets are indeed said in the 1592 version to be 'denuo recogniti'." Indeed; but denuo recogniti means 'edited anew', which could stand above any freshly edited text of the poets. Chris Heesakkers, who has written several books about Janus Dousa pater, has never heard of this edition; and it is not listed in any of the library catalogues that I could consult. The entry devoted to it in the Bipontine Index Editionum is rather generic, and does not appear to quote an actual title ${ }^{18}$. Professor Heesakkers very reasonably suggests that the edition may never have existed, and all references to it are due to someone who misunderstood the word 'denuo' in the title of Dousa filius' 1592 edition.

$\mathrm{M}^{\mathrm{c} K} \mathrm{Kie}$ also refers to the last edition of Catullus published by Hieronymus Avantius (this is how he is known to Catullan scholars, but he appears to have spelt his name in Latin as Avancius) or Girolamo Avanzi, one of the most influential Catullan scholars of all times, which he dates to about 153440. Elsewhere he refers to it as the "Trincavellus" edition, and notes that it is "extant in a single copy in the Bodleian" (p. 97, n. 295) ${ }^{19}$. This important but extremely rare edition is puzzling in many ways. It contains no date, and it is not specified where it was printed or by whom. It contains a newly emended text of the poems of Catullus, a biography of the poet, and three epigrams celebrating this new edition; however, the title runs Catullus, Tibullus, Propertius, Gallus restituti per Hieronymum Avancium, Cardinali Farnesio dicantur ..., and in the preface Avanzi introduces a newly emended edition of the poems of Catullus, Tibullus and Propertius, in each case followed by a biography of the poet.

The view that the Oxford copy is the only one to survive goes back to a handwritten note by a former owner that is conserved alongside $\mathrm{it}^{20}$.

${ }^{18}$ Catullus, Tibullus, Propertius cum Galli fragmentis et Peruigilio Veneris ... , Biponti 1783, p. xlviii: "Cat. Tib. Prop. Lugd. Bat. 12. ed. Jano Dousa fil. cum pervigilio Veneris \& suis in Cat. Tib. Prop. conjectaneis."

${ }^{19}$ It would have been difficult to study this rare book without the help of Bruce BarkerBenfield at the Bodleian Library, Inge Dupont at the Morgan Library, and Giuseppe Gilberto Biondi and Giovanni Maggiali at the Università degli Studi di Parma. Of course I alone am responsible for the views expressed here.

${ }^{20}$ Bruce Barker-Benfield has suggested that the hand may be that of the collector Reginald Heber (1783-1826). 
However, I found another copy of this book at the Morgan Library in New York; a third one is listed in the catalogue of the University of Aberdeen Library. I would not be surprised if another copy turned up in one of the great Italian libraries, not all of which have easily accessible online catalogues. Copies of the book must have circulated in Italy; Achilles Statius, who lived in Rome, shows knowledge of it in his commentary of 1566.

The notion that this edition was printed by Trincavelli ultimately derives from a comment in Gesner's Bibliotheca Universalis of $1545^{21}$. But on its first page we see a rectangular printer's emblem that shows a putto holding an olive branch, who is leaning onto a tree-trunk; Greek phrases have been added along its four sides. This emblem is that of the printer Bartolomeo Zanetti of Casterzago near Brescia, who is known to have worked in Venice from 1535 until $1543^{22}$. In the years 1535-37 Zanetti collaborated with the doctor and humanist Giovanni Francesco Trincavelli to publish a series of Greek editions, as is shown by the text "Venetiis in aedibus Bartholomaei Zanetti Casterzagensis. aere vero, \& diligentia Ioannis Francisci Trincaveli" in the colophon of Philoponus, Contra Proclum, which is dated May 1535, and by similar formulas in editions of Aristotle, Epictetus and Hesiod, and of other works by Philoponus.

So Avanzi's last edition of Catullus was printed by Zanetti. Was he aided in this by "the money and the diligence" of Trincavelli? I suspect that he was not. There is no indication Trincavelli ever collaborated with Zanetti to publish anything except for a series of Greek texts, mostly philosophical ones. A preface was written for these by Trincavelli; but that before the poems of Catullus is signed by Avanzi. No value should be attached to the

${ }^{21}$ Conradus Gesner, Bibliotheca Uniuersalis, siue Catalogus omnium scriptorum locupletissimus ..., Tiguri 1545, fol. 327v: "HIERONYMUs Auantius poëtas quosdam restituit, nempe Catullum, Tibullum, Propertium: qui Venetijs apud Trincauellum nuper impressi sunt."

${ }^{22}$ On Bartolomeo Zanetti see R. Cessi, "Bartolomeo e Camillo Zanetti tipografi e calligrafi del '500”, Archivio Veneto-Tridentino 8, 1925, 174-82; G. Borsa (ed.), Clavis Typographorum Librariorumque Italiae, Aureliae Aquensis 1980, at I, 351; F. Ascarelli - M. Menato, La tipografia del '500 in Italia, Firenze 1989, 278f., cfr. 368. The emblem in Avanzi's edition of Catullus is identical to that in L'Ecclesiasto di Salomo, tradotto dal la Ebraica vertia in lingua Toscana, \& con nuouo commento dichiarato per Antonio Brucioli, Venetia 1536 (the colophon states: "Impresso in Venetia per Bartholomeo Zanetti"). The Greek text in the

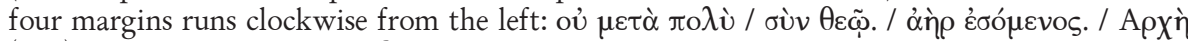

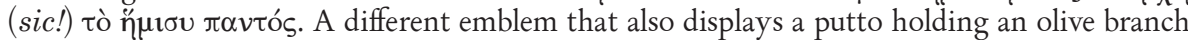
and leaning onto a tree-trunk, with the trunk not on the right but on the left and many other differences, appears in Ioannis Grammatici in primos quatuor Aristotelis de naturali aus cultatione libros commentaria, Venetia 1535 (colophon: "Venetiis in aedibus Bartholomei Zanetti Casterzagensis, aere uero, \& diligentia Ioannis Francisci Trincaueli.") and was found by Vaccaro in a Venice 1537 edition of Giovanni Villani's Croniche. For the first emblem see G. Zappella, Le marche dei tipografi e degli editori italiani del Cinquecento, Milano 1986, vol. 2, fig. 988, cfr. vol. 1, 314f.; for the second see ibid., vol. 2, fig. 987, and E. Vaccaro, Le marche dei tipografi ed editori italiani del secolo XVI nella Biblioteca Angelica di Roma, Firenze 1983, 372, fig. 516. 
fact that Gesner attributes the edition to Trincavelli: he wrongly considers him a printer, and believes that the book actually contained the works of Catullus, Tibullus and Propertius ${ }^{23}$. The Swiss bibliographer clearly did not have superior knowledge about the circumstances of its publication, but he had simply glanced at its front page, where he found an emblem that he had already seen in volumes that had been edited and financed (but not printed) by Trincavelli, and he had made the incorrect inference that Trincavelli was the printer responsible for all these books.

Zanetti dates his books in the colophon. Avanzi's last edition of Catullus has no colophon and therefore no date. Avanzi and Zanetti were evidently planning to publish a volume that contained the poems of Catullus, Tibullus, Propertius and Gallus, as is shown by the title and the preface, but for reasons that remain unclear only the title page, the preface, and the text of Catullus were printed.

The title indicates that the book is dedicated to Cardinal Farnese, but Avanzi states in the preface that the dedicatee has just become Pope and has taken up the name of Paul III. Alessandro Farnese was elected Pope on 13 October 1334. Avanzi also refers to Girolamo Aleandro (Hieronymus Aleander), whom he calls papal legate to Venice. Aleandro held this office from 1533 until 14 August $1535^{24}$. Evidently the title page of the book was set to type in 1534 some time before the news of Farnese's election reached Venice, and the preface was written after that event, but while Aleandro was still papal legate to the city, or at any rate before the news of his dismissal reached Venice. So the extant parts of this book were completed in late 1534, or in the first eight months of 1535. It is better to speak of completion rather than of publication: it is not clear what the latter would have meant in the case of a volume that was left incomplete.

DÁNIEL KISS

Ludwig-Maximilians-Universität München

Daniel.Kiss@klassphil.uni-muenchen.de

${ }^{23}$ See n. 21 above.

${ }^{24}$ G. Alberigo in Dizionario Biografico degli Italiani (2, 1960, 128-135) s.v. Aleandro, Girolamo, at p. 132. 
